\title{
The Concept of Righteousness
}

\section{in the Literary Prose of M.A. Tarkovsky}

\author{
Nikita A. Valianov* \\ Siberian Federal University \\ 79 Svobodny, Krasnoyarsk, 660041, Russia
}

Received 24.02.2015, received in revised form 16.03.2015, accepted 13.06.2015

The paper deals with the image of a righteous character traditional for Russian patriarchal culture. The image of the righteous person is embodied in various artistic samples of Russian literature manifested in the form of the "wise old man" and presented in the literary works of Siberian writer M. A. Tarkovsky. The examples of representative literary works are used to determine the type of righteousness characters close to the primordial hagiographic and folk traditions (a preceptor, a martyr, a keeper, a holly fool).

Keywords: righteous, modern traditionalist prose, M. A. Tarkovsky.

DOI: 10.17516/1997-1370-2015-8-7-1459-1468

Research area: philology.

\section{Introduction}

As a native Russian phenomenon Righteousness (Pravednichestvo) defines spiritual and moral guidelines of society, has a special significance for the national culture. As a socio-cultural phenomenon that combines the experience of intense spiritual life, the involvement of man to the world of the ideal of being, to a higher truth, Righteousness looks for opportunities for finding oneself in the truth (Tarasov, 2007, 239). A.B. Tarasov believes that righteousness acts as a representation of the saints, who had a virtuous life in the world, or non-canonized or locally venerated saints and pious people of the church environment. The author believes that the foundation of asceticism in the Orthodox tradition is a righteous life, irreproachable orthodoxy, popular veneration and miracles (Tarasov, 2006, 45). As a "powerful factor of national life", the ideal of righteousness is meekness, humility, modesty (Sohriakov 2010, 435). The tradition of righteousness that was launched by the originator and liturgical texts, and later embodied in the works of Russian artists, today is reflected in monographic research and is interpreted as an inner necessity, the need of the soul, freedom (ibid, 433).

The Russian literary tradition-righteous character is given a special place. The image associated with the Orthodox values, deep and fully revealed in the ancient literature and is associated primarily with the figures of the holy fool and the saint. The Russian literature of $18^{\text {th }}$ century puts the image of the righteous person to

(C) Siberian Federal University. All rights reserved

* Corresponding author E-mail address: nick.valyanov@yandex.ru 
the background, but it is always present in the texts of N. Karamzin, A. Sumarokov and M. Kheraskov. The change of emphasis is determined by the fact that the literature of Peter the Great's era is moving away from the national canons laid by the old Russian culture: it becomes europeanized, translating thus a humanistic perspective in the socio-political context. In the literature of the first half of the $19^{\text {th }}$ century we see a kind of righteous person, embodied in the "little man" - a worker who overwhelmingly turns to God, living according to His commandments, "humiliated and insulted" - but the character himself is entrenched in the human moral truth, the idea of carrying on the Earth life transformation. The type of a righteous character takes its shape in the second half of the $19^{\text {th }}$ century in the works of Turgenev, Leskov, Dostoevsky, Tolstoy, Chekhov (Khalizov, 1997, 112). The keen interest in the phenomenon of righteousness is manifested in the era of modernism - in the works of L. Andreev, M. Gorky, I. Shmelev. Later this theme is revealed on pages of works of the "villagers" - V. Belov, A. Solzhenitsyn, F. Abramov, V. Rasputin, V. Astafiev, and becomes absolutely topical in the texts, completing the postmodern era (Soldatkina 2014).

The "Village prose" summarizes the type of a righteous person, pictured on pages of works of representatives of classical literature of the 19th century. The essence of righteousness for the characters of the "village prose" is determined not "by the pursuit of holiness, but as a desire to live in accordance with truth and harmony with itself and the world" (Koroleva, 2009, 82). According to S. Smirnova, righteousness is "not limited to the sphere of the divine, and covers the earthly way of human's life and implies maintaining a godly way of life, adherence to religious precepts" (Smirnov, 2005, 13). A. Yu. Bolshakova notes that the works of the "village prose" show a type of a righteous character that is embodied in the form of "a wise old man", who is a stable component, along with "Mother Earth", " $a$ naïve child" ("ditiatia") are used in the domestic literary tradition (Bolshakova 1999, 16).

\section{The Problem Statement}

The righteous character is in the center of attention of writers, who trail the direction of traditionalism at the turn of $20-21^{\text {st }}$ centuries, B. Ekimov (Kovtun 2012), R. Pogodin, E. Rodchenkova (Iakusheva, 2012). The literary experience of M.A. Tarkovsky is interesting in this respect. Tarkovsky develops the ontological direction of modern traditionalism that was put forward by the prose of Viktor P. Astafiev: Tarkovsky turns to the image of fishermen, taigamen, adding poetry to peasant labor on the banks of the Yenisei river. The writer presents a number of characters, who can be classified as righteous people - open, kind, compassionate, capable of forgiveness and self-sacrifice. These are Uncle Tolia Popov (Vekovechno - "Eternally"), auntNadia(Ledokhod-“IceDrift"), Grandmother (Babushkin spirt - “Grandma's Alcohol”), Vania (Fundament-"Foundation"), Ivanovich (Stroika Bani - "Construction of Bania") and others.

\section{The Images of Teacher and Mentor}

The tale Stroika Bani - "Construction of Bania" (1998) is a landmark work of Tarkovsky, finalizing his early works. The main character is Ivanovich - an old man, who gave his entire life to taiga, but never managed to devote his only son Sergei to this mystery. Sergei had been living for several years in a city. The main part of the text is devoted to building a new bania (bath-house) - the author shows how Ivanovich becomes transformed at the construction site: “... he knew that it was necessary to bring to an end, and that he would rather die than allow the peasant experience accumulated by centuries to 
disappear" (Tarkovsky, 2009 284). He emphasizes the connection of the character with his kin, which is typical for the works of the "village prose". The main thing for Ivanovich was to convey his life's hereditary, but he realized that the fulfillment of his last will was not meant to be. Righteousness of the character is in his humility: only "a man of great soul could endure any quirks of the son" (Iarantsev, 2009), a decent respect to the life skill: "These pages are a real poem of labor, non-vanity skill where a person carries out his (her) main functions: the harmonious transformation of the world" (Remizova 2007, 143). The sense of a life lived with dignity and the need for such a worthy end for the character becomes an important spiritual support. At least, Ivanovich was not afraid of death, although sometimes he would regret parting with the beloved world, which every year becomes "all native, understandable and grateful” (Tarkovsky, 2009, 320).

Ivanovich has his love for his native land and people around, so it allows us to see how righteous his life is. He felt his dead wife beside him at difficult times, and blamed only himself for letting his son go. The plot is reminiscent of the parable of "the prodigal son" - Sergey leaves the village, and his father, full of the true faith and love for him, forgives and waits. There is no penance within this literary narrative, but the story Sergei of suggests it. The plot of the return of the prodigal son is one of the core to the modern traditionalism as a whole, it structures the epic novel of F.Abramov's "Brothers and Sisters", the texts of A. Solzhenitsyn, stories by V. Rasputin and B. Ekimov (Kovtun 2014). Leaving the father's house symbolizes the destruction of the patriarchal culture: Tarkovsky's characters, leaving their native space, lose their vital foundations, thus dooming themselves to voluntary homelessness, orphanhood. The story surrounds Ivanovich with the same diligent, righteous people - Nicholas Afanasievich (nicknamed "God"), he "wore a jersey covered with neat small patches $<$... $>$ and he was remarkable for his hardworkingness, thrift" (Tarkovsky, 2009, 299-300), he had a talent to help all those in need. We may note that patched clothes was a corporate sign of foolishness, the image of the holy fool in the literature of the second half of the twentieth century, one of the first was introduced by F. Abramov (Kovtun 2010).

The name / first name of the character Ivanovich is peculiar for being an originally Russian name, his occupation is work on the ground. This "hidden hero" is a hereditary farmer. The image of the bath-house, the construction of which overstrained the character, is contradictory. On the one hand, the bath-house is a the profane, transitional space where protective amulets do not work, but on the other hand, he puts all his soul and heart to this construction site. This bath-house appears as a symbol of purification, spiritual and physical renewal. Before going to the steam room, the character experiences "children's excitement as before a long-awaited event", he becomes purified from earthly sins and gets a rebirth. Feeling the "baby purity", Ivanovich feels that "his memory was set free" and how "freely his memories, important and familiar, fly before his eyes" (Tarkovsky, 2009, 325). The plot of the story refers to the text of V. Shukshin "Alesha Beskonvoinyi"." The bath-house for Ivanovich is just the same sacred item, just as for Shukshin's "wierdo" - Kostia Valikov, who only there experienced the "feast of the soul". These both texts similarly describe the preparation of the characters for going to the bath-house, and their feeling of relief that they are experiencing.

The final of the story, prompted by the logic of the previous events, seems inevitable: the soul of Ivanovich, that "has never been so clean", ascends to heaven. In the story the character appears as a teacher / master, leaving his knowledge behind. The knowledge is hidden 
in the earth itself, in small and large buildings, which he erected. Sergei rejects the legacy of his father and does not become his follower, yet the author gives hope that the neighbor boy Kolia, who appears in the final of the story, can revive and glorify the peasant labor. But Sergei is at a crossroads - his urban hostel is at the same intersection, where it is necessary to choose your path / destiny. The image of the marginal, leaving his ancestral lands in the name of urban ghostly happiness, was brilliantly illustrated in mature stories of V. Shukshin (Glushakov, 2009).

Uncle Tolia Popov is a righteous character from the story "Vekovechno" (Everlasting/for centuries) (2001). He recently buried his wife. He lives with the help of fishing labor - every day goes hunting, fishing. Despite his advanced age, he "over the years somehow became more and more vigorous, witty and restless" (Tarkovsky, 2009, 8). The righteousness of the character is manifested in his selfless mentoring, selfless service to his destiny. Despite the spat with his neighbor hunter Mitia Shliakhov, he advises him on how to put a duralumin patch, "Put in on grease - it will work for centuries" (Ibid: 9). The expression "everlasting" (for centuries) (which, as we see, is issued in the title story) just like a word of God, "echoes along the banks and ridges" (Ibid). These righteous traits we see in the scene when he met a peasant on the mountain, and the peasant was surprised that the weather was getting better, yet Uncle Tolia replied: "that is what I ordered!" Of course, it is an ironic image, but it agrees with that fusion of the world and neighborhood that is described in the text, which marks the fullness of human existence.

The poetics of "crystallization" of the character's image has an important literary and aesthetic significance here: it is closely related to the concept of living and transparent mineral water. The water in which the character's face becomes "dissolved", appears as a symbol of rebirth and as something that gives hope for enlightenment of the human soul: "Life of the old man every day doused the new crystal clarity, and the more turbid these eyes seemed from outside, the more transparent it was to look into them from uncle Tolia's dry and hot guts" (Ibid, 8). The description of water - crystal clear - we see when the character catches fish, when crushes hummocks and builds stoves from clear blue pieces of ice.

Then there is this remarkable scene in the story when Mitia Shliakhov visits his grandfather Tolia, who is in bed due to a recent heart attack. Here it reveals the image of the wise old man in its entirety, a righteous man who is ready to forgive neighbor for misconduct. The image is close to the icon-painting, "he lay with a parchment-yellow face, with dark mustache, a red quilt, disengaging his hand with flat fingers" (Ibid, 12). The author notes: "... he continued to be out of his body", and Mitia tried to find an excuse for the dog's stealing of a mink, he just makes a gesture of forgiving. This meeting is presented as Mitia's confession, who is ready to repent for all his sins and accept the foundations of human live that were observed by Uncle Tolia Popov. The resistance, positive energy, kindness and merciful nature of the main character are transmitted to Mitia, he felt that his soul became "at ease $<\ldots>$ as if with the movement of uncle Tolia's hand not only this unfortunate mink, but also all other sins of his life became gone" (Ibid same).

\section{The Images of Sufferer and Keeper}

Women's images hold a special place in the works of the writer. The ideal woman is usually pictured as a mother. It is the figure of an old merciful woman that the author considers as an incarnation of the merciful motherhood. It is on her the author places his hopes concerning enlightenment of the Russian countryside, 
preserving its traditions. A holy attitude to the past characterizes the female characters as true righteous people, who became a tradition's "storage unit" (White, 1986, 17).

A type of a righteous woman is presented in the story "Babushkin Spirt" (Grandma's Alcohol) (2004). The image of a compassionate old woman is revealed in the work through her relationship with a close one (son, daughter and grandson). The main character - Glafira Prokop'evna (reminiscent of the old women of V. Rasputin and V. Astafiev) worked all her life in the local bakery, but under the pressure of circumstances was forced to go against their conscience and start trading this "disastrous vile potion" that became the only currency in the village (Rusakov, 2004). The female character appears in the third part of the story. The image of the good old woman is permanently mixed with suffering. The feeling of sadness and panic and perpetual anxiety entail nervous disorders, illnesses - Glafira Prokop'evna was embarrassed to call the ambulance, always felt guilty before all the world. It is worth noting that the character's traits have much in common with Matrena from Solzhenitsyn's work, and Rasputin's old woman Anna (The Last Term), who felt awkward and felt guilty to her children for her death, that the death had not come on time as it had been expected".

Tarkovsky's female character went on a terrible thing, and feeling doubt and guilt - she was aware of the gravity of her sin, but she wanted "any time to honor and not to insult the surrounding people with a hint for their gravy addiction". We see how the story reveals the image of a martyr, who humbly accepts all hardships of life on earth. Reducible to the apocryphal text and native of plot for a number of literary works of the "village prose" the motive "of going through Hell" is pictured in the story of Tarkovsky. The grandma does not separate her fate from the fate of the good-for-nothing villagers. The author and the text uses the device of the paradox - the most sinful, it would seem, character who is associated with the potion, is described by the canons of righteousness (Klimova 2010, 115-127).

The split of the rural space into two camps the sober and the drunk (heaven and hell) where one party survives at the expense of the other, is explained by the destruction of a tradition, a former lifestyle. Decomposition of integrity of residents of the village leads them to death, or else to the construction of a new spiritual community, which can be seen within the narrative. The internal division is observed in the characters Gal'ka and Diad 'ka, who have no family, and who "lack their soulmates", in the small character Kol ka, growing up in single-parent family. The grandmother, who is on the line of this split, turned to sinful humanity watching their meal (daughter, son, local alcoholics), she feels even more pain. In the old-Russian text the Mother of God prays to the Lord for forgiveness of Christian sinners, the Tarkovsky makes a different literary decision, which can be comparable to the apocrypha: the grandma redeems the sins of the villagers with her own death, as is evidenced by the symbolic image of the yellowhammer bird at the end of the story. The death of the grandmother who comes suddenly, dramatically changes the behavior of the characters, their attitude to life. Those Gal 'ka and Diad ka, who "were the grandma's eternal pain and concern", on the day of her death become transformed: he was "extremely concerned, serious and got stronger" (Tarkovsky, 2009, 184). And Gal 'ka, who did not care about her mother much, ran home to bring black glasses, only to alleviate the suffering of the old woman, who felt blinded by the sun.

Similar to M.A. Tarkovsky's other characters - Ivanovich, who became blessed by his new bath-house or Mitia Shliakhov, who received blessing from uncle Tolia Popov, the grandma goes through a rite of passage. The episode is 
decorated with a number of folk motifs, which allow us to conclude that the female character is "the chosen one". This is noticeable when people bear the grandma on a stretcher: the sun illuminates her "differently, not like the others", or when nearby people try each time "to touch the grandmother's emaciated body $<\ldots$.. in order to communion" (Ibid, 185 ). The scene when the helicopter "three times cannot land $<\ldots>$ when the blackened and furious skies are unwilling to give the grandma's body to the ground" (ibid, 184). It would seem that the final of the story is tragic, however, the image of yellowhammer spring bird introduced by the author (which is to "put a bandage on the bleeding soul with its silver ditty") gives hope for recovery of the national spirit. In the folk tradition, this image is associated with the change of weather and better times.

Tolerance to the sin and the hope its redemption are signs righteousness that unite the grandmother and Aunt Grania Khokhlova ("Spoon of Soup", 1998) and Aunt Nadia from ("Ice Drift", 2003). Just as a lonely old woman Agafia from V. Rasputin's story "Cottage" Aunt Nadia lives his life, doing a man's job. Agafia built her own house, whereas Aunt Nadia was a fisherwoman, who "went into the forest to check the traps with a backpack and a gun, with a staff in her hand, warm pants, a jersey and huge gloves" that remotely resembles the type of " $a$ warriorlady" recreated in Rasputin's later works. The feat of the peasant woman lies in building and maintaining a home.

The wise old woman, who saw a lot in her life (the death of two husbands, daughter), managed to survive even during the destruction of her native village. The decay of the rural world in the story is associated with a senility house, resembling a sinking ship. Being a witness to the destruction of the village, the old woman does not lose her connection to it, she appears as the last guardian, a genius of the terrain (Kovtun 2013).
Aunt Nadia in new home happy with all the same way: "... in the same manner she arranged the furniture, spread rugs, hung all that hung on the walls of the old house" (Tarkovsky, 2009, 50). The image of Aunt Nadia (semantics of the name is associated with hope) is a type of an ascetic person, a version of the national image - the keeper of ancient foundations.

The female character's birthday that was marked as a feast symbolizes the harmonization of the world, unity of the old woman with all inhabitants of the former and present village, the festival continued for three symbolic days. I.L. Balaian emphasizes Christian features in the image of the old woman, noting faith, resilience, hard work, caring for others, commitment to the traditions, kindness and love for people (Balaian, 2014, 137).

\section{The Image of Holy Fool}

The author gives special attention to the type of holy fool, one of the most significant in Russia (Panchenko 2005, 26-42). The character endowed with genuine righteousness manifested in the form of the holy fool is found in "The Foundation" (2004). Homeless Van'ka, who is met by the protagonist by chance - "vaguely hanging out" in a drunken company - on the one hand, did not initially fit into the named circle, and on the other he had an opportunity to be "taken out" of it, that basically happened (when Fedor took the beggar to build the foundation of the house). There was a reason why the homeless person joined the drunken company: uniting the fate of characters, the author highlights their marginalization. Van`ka is represented as a transitional type: initially claimed to be a tramp later he becomes reborn as a righteous person. The journey from the sin to its repentance passes through the test of his life $-\mathrm{t} e$ construction of the house / world. For Tarkovsky the process of construction has traditional poetics of purification when there is a dialogue of masters 
souls. Van'ka - beggar refuses to take money for the work, and feels compassion and wants to pay good for the good. Reliability, forgiveness and assistance to anyone who needs it shape the inner core of the character.

Referring to the ancient Russian sources, the author explicitly defines the core mission of Vania, "after having returned from the bottomless antiquity to mourn our silly time" (Tarkovsky, 2009, 42). Frequent author's appeal to the character's blindness implies inner purity of the worldview, a view from the inside, reminiscent of the iconographic sacred. He emphasizes the contradictory image of the beggar with his nakedness, represented on the one hand, as a kind of separateness from the rest of the world, a shameful thing (naked people), on the other as a feature of sacred foolishness. Preparation of the beggar for his death occurs quite consciously: "Back in the house and catching his breath, he puts on clean trousers, a shirt and socks and stands in preparation for the main" (Ibid, 46). The description is very symbolic - from underwear white shirts to shoes that Vania had a hard time putting on, but he did so not to wear these shows: "a foot unrecognizably drawn by the black socks, by some miracle gradually crept into a black cloth shoe, which angularly pouted if it was stuffed with potatoes"(Ibid, 47).

The author's understanding of literary space ("Village $\rightarrow$ City") in literary reflection suggests its relation to existential concepts ("Life $\rightarrow$ Death"). Vania who suddenly decided to leave the village, in essence, is saying goodbye to life and is getting ready for his long haul to the other world. Moreover, the river is the only conductor, symbolizing the transition from one space to the other. Fyodor's last plea is that the no one would come, in order not to baffle prostrate Vania: the plea sounds like the last word in which one may see the hidden hope for the best. The borderline state of the character shown by the author at the final of the story involves finding a threshold for a new life: “... surfacing from the booze while staying in a quiet breakdown, [he] was slowly going into the shore and was shining from within" (ibid, 47). In fact, the stage of sleep is marked as a scene of death and a sudden thought of Fedor ("What if he suddenly died?") predicts the future. The final picture of the darkened shores of a huge river, which "goes curvedly down the horizon, , leaving the void" (symbolizing the Summer), provides the reader with a definitive answer Vania takes persistence, which he had sought in his life for so long.

\section{Conclusion}

Thus, M.A. Tarkovsky keeps the phenomenon of righteousness within the traditionalist prose. As in the literature of 1970-1980-ies, this phenomenon appears as "a moral-psychological landmark, a pledge of hope for salvation" (Sokhriakov 2010, 458). Literary texts of the author have symbolic mythopoetic, ideological content - introduced in the narrative text with the help of traditional motifs, images and stories of Russian People's Orthodox culture.

The image of a righteous character, as described in the texts of the writer, is original. One of the distinctive features of the character becomes a unity with the environment, which the character feels and tries to follow. A wise understanding of life, resigned acceptance of death, a close relationship with the land, taiga, Yenisei suggest the merger of man with deified nature. The righteous character is remarkable for his selfless service to destiny, he is a master, shares his knowledge with people close to him so that his talent would have a continuation. Tarkovsky's righteous character is truth-seeker who tries to tell about this life something unspoken. These characters are trying to keep their land, memory, tradition. Heart disease as the cause of death of many saints is not 
accidental, symbolizing the inextricable link with the fate of Christ's crucifixion (heart as a conductor with God).

In the small Siberian prose the writer meets a traditional Russian culture motive of butlers. In Orthodoxy excessive love of vodka is condemned and understood as sin or temptation. For Tarkovsky's heroes - it is part of their difficult lives in the north. Remizova denotes wine drinking as a significant definition of national identity: "At the bottom of each next wineglass Russian people look for outlines of the last truth with growing inquisitiveness" (Remizova, 2000). Tarkovsky's character is the only one who drinks intelligently. $\mathrm{He}$ understands the truth in his terrestrial (drunken) state. His transition to the transcendental state and awareness of sin and repentance allow to transform sinners into righteous people. The character sincerely mourns his imperfection and comes to understanding of a different existence.

The peculiarity of the artistic tradition of M. Tarkovsky is that he is the character returns from the city to the country, believes in the saving power of this process, in contrast, for example, to the late V.M. Shukshin. Actually, the classical understanding of the righteous person for Tarkovsky is synchronized with the image of a recluse, escaping from the bustle to taiga. The author's mythopoetical images of the river and homeland are deeply entrenched in the folk tradition and help to understand the integrity of peasant nature, endowed with, on the one hand, children's naivety, on the other wisdom, humility and meekness, deep faith in human. These people are "chosen ones", which is indicated by the ritual of "Communion" initiation into the mysteries of the "other" natural being, the truth which they seek to comprehend. The changes caused by life circumstances, cannot break down the nature of the righteous people. Having tested for their strength, they remain true to their principles and ideals. From Tarkovsky's point of view, staying still (samostoianie) is a defining feature of the Russian character and is a pledge of greatness of the people's righteous soul.

\section{References}

1. Balaian, I.L. (2014) Problema lichnosti v rasskazakh M. A. Tarkovskogo [The problem of personality in the stories of M.A. Tarkovsky]. ASU Herald, 1 (134) 135-139.

2. Belaia, G. (1983) Khudozhestvennyi mir sovremennoi prozy [The artistic world of contemporary prose]. Nauka, Moscow. $191 \mathrm{p}$.

3. Bolshakova, A.Yu. (1999) Fenomen derevenskoi prozy. Russkaia slovesnost' $[$ The phenomenon of rural prose. Russian literature], 3, 15-19.

4. Glushakov, P.S. (2009) Ocherki tvorchestva V. M. Shukshina i N. M. Rubtsova: klassicheskaia traditsiia i poetika [Essays on creativity of V.M. Shukshin and N.M. Rubtsov: classical tradition and poetics]. Monograph. Riga, Rota. $279 \mathrm{p}$.

5. Klimova, M.N. (2010) Ot protopopa Avvakuma do Fedora Abramova: Zhitiia "greshnykh sviatykh" v russkoi literature. [From Avvakum to Fedor Abramov: Lives of "sinner-saints" in Russian literature]. Moscow: Indrikis, 136p.

6. Koroleva, S.Y. (2009) Obraz pravednika v “derevenskoi proze" V. Rasputina. Vestnik Permskogo universiteta. Rossiiskaia $i$ zarubezhnaia filologiia [The image of the righteous in the "village prose" of Rasputin. Bulletin of the University of Perm. Russian and foreign philology], 1, pp. 79-89. 
7. Kovtun, N.V. (2012) House-spirit, Master, Pinochet: a Patriarchal Myth in the Late Traditional Prose. Journal of Siberian Federal University. Humanities and social sciences, 2 (5), 255-264pp.

8. Kovtun, N.V. (2014) Motiv bludnogo syna v sovremennoi traditsionalistskoi proze. Pritcha v russkoi slovesnosti: ot Srednevekov'ia k novomu vremeni [The motive of the prodigal son in modern traditionalist prose. The parable in Russian literature from the Middle Ages to Modern Times]. Monograph. Novosibirsk Omega Print, pp. 435-447.

9. Kovtun, N.V. (2013) Patriarkhal'nyi mif v traditsionalistskoi proze rubezha 20-21 vv. Sibirskii filologicheskii zhurnal [The patriarchal myth of traditionalist prose abroad in 20-21 centuries. Siberian Journal of Philology], 1, pp. 77-87.

10. Kovtun, N.V. (2010) Iurodskoe stranstvie v poetike F. Abramova. Sibirskii filologicheskii zhurnal [Journey of righteous fools in the poetics of F. Abramov. Siberian Journal of Philology], 3, pp. 93-102.

11. Panchenko, A.M. (2005) Ia emigriroval v Drevniuiu Rus' [I emigrated to the Ancient Russia]. St. Petersburg., Star. 544p.

12. Remizova, M. S. Postsovetskaia proza i ee otrazhenie v literaturnoi kritike [Post-Soviet prose and its reflection in literary criticism]. Moscow: Sovpadenie Publishing, 2007. 447p.

13. Remizova, M. S. (2000) Rusi yest' veseliye piti [Russia has cheerful drinking]: available at: http://www.ng.ru/culture/2000-08-03/7_rusi.html

14. Rusakov, E. (2004) Dobraia babushka i zlaia zhizn' (o povesti Mikhaila Tarkovskogo "Babushkin spirt”). Krasnoiarskii rabochii [Good and evil grandmother lives [of the story of Michael Tarkovsky "Babushkin alcohol"] Krasnoyarsk Worker, 115, 3.

15. Smirnova, S. A. (2005) Sviatost' kak fenomen russkoi kul'tury (semanticheskoe i lingvokul'turologicheskoe opisanie): avtoref. dis. ... kand. filol. nauk. Arkhangel'sk. [Holiness as a phenomenon of Russian culture (semantic and linguistic-cultural description): Abstract. Dis. ... Cand. filol. Sciences. Arkhangelsk]. 25 p.

16. Soldatkina, Ya. V. Evolyutsiia tipa "geroia-pravednika"v sovremennoi russkoi proze. Antropologicheskie sdvigi perelomnykh epokh i ikh otrazhenie v literature. [The evolution of the "the righteous character" in contemporary Russian prose. Anthropological shifts of the pivotal era and their reflection in literature]. Coll. scientific. In 2 parts. Grodno: YKSUG, Kupala. Part 1. pp. 28-34.

17. Sokhriakov, Yu. I. (2010) Russkaia tsivilizatsiia: Filosofiia i literatura [Russian Civilization: Philosophy and Literature]. Moscow: Institute of Russian civilization. 720 p.

18. Tarasov, A. B. (2006) Ponimanie pravednichestva. Znanie. Ponimanie. Umenie [Understanding of righteousness. Knowledge. Understanding. Ability], 1, 41-47.

19. Tarasov, A. B. (2007) Pravednichestvo. Entsiklopediia gumanitarnykh nauk [Righteousness. Encyclopedia of Humanities], 3, 239-240.

20. Tarkovsky, M. A. (2009) Enisei, otpusti! Kniga prozy. "Istoricheskoe nasledie Sibiri”. [Yenisei, let it go! The book of prose]. Novosibirsk: Publishing House "Historical Heritage of Siberia".352p.

21. Tarkovsky, M. A. (2009) Zamorozhennoe vremia. Kniga prozy. "Istoricheskoe nasledie Sibiri" [Frozen time. The book of prose]. Novosibirsk, Publishing House "Historical Heritage of Siberia". 416p.

22. Khalizev, V. E. (1997) "Geroi vremeni” i pravednichestvo v osveshchenii russkikh pisatelei 19 veka. Russkaia literatura 19 veka i khristianstvo. [Heroes of the time and righteousness in the 
coverage of Russian writers of the 19 century. Russian literature of the 19 century and Christianity]. Moscow, Moscow State University, pp.111-119.

23. Iakusheva, O. A. (2012) Tema pravednichestva v novoi derevenskoi proze. Vestnik Brianskogo gosuniversiteta [The subject of righteousness in the new village prose. Bulletin of Bryansk State University], 2 (2), pp. 178-180.

24. Iarantsev, V. (2009) Zavorozhennyi Eniseem. Sibirskie ogni [Spellbound by the Yenisei. Siberian Lights]: available at: http://magazines.russ.ru/sib/2009/10/ia31.html

\section{Концепция праведничества}

в художественной прозе М.А. Тарковского

Н.А. Вальянов

Сибирский федеральный университет

Россия, 660041, Красноярск, пр. Свободный, 79

В статье рассматривается традиционный для русской патриархальной культуры образ героя-праведника, воплощенный в различных художественных образиах отечественной словесности (древнерусской и классической литературе, «деревенской прозе»). Тип праведного героя, явленного в облике «мудрого стариа», представлен и в литературном творчестве сибирского писателя М. А. Тарковского. На примере наиболее репрезентативных произведений определяется тип праведности персонажей, близкий к исконной агиографической и народнобытовой традиции (наставник, страстотерпец, хранитель, юродивый).

Ключевые слова: праведник, современная традиционалистская проза, М.А. Тарковский.

Научная специальность: 10.00.00 - филологические науки. 